\title{
A Causal Model of Gastronomy Tourism Development Focusing on Cultural Heritage Values in Maha Sarakham Province, Thailand
}

\author{
${ }^{1}$ Mallika Jecan , ${ }^{2}$ Asst. Prof. Dr.Thirachaya Chaigasem, ${ }^{3}$ Dr.Somruthai Soontayatron, ${ }^{4}$ Assoc. Prof. \\ Dr. Grit Ngowtanasuwan
}

${ }^{1} \mathrm{Ph} . \mathrm{D}$. Student of Tourism and Hospitality Innovation Management Department, Faculty of Business Administration and Accountancy.KhonKaen University, Thailand

${ }^{2}$ Head of Ph.D Program in Tourism MICE and Hospitality Innovation Management

Faculty of Business Administration and Accountancy KhonKaen University, Thailand

${ }^{3}$ Faculty of Sports Science, Chulalongkorn University, Bangkok. Thailand,

${ }^{4}$ Faculty of Architecture, Urban Design, and Creative Arts, Mahasarakham University, Thailand

Corresponding author

Asst. Prof. Dr.Thirachaya Chaigasem

Head of Ph.D Program in Tourism MICE and Hospitality Innovation Management

Faculty of Business Administration and Accountancy

KhonKaen University, Thailand

\section{Abstract}

The present study sought to address the following objectives: 1) to investigate circumstances, contexts and gastronomy tourism resources based on the cultural heritage values in Mahasarakham; 2) to examine formulation of the innovative model for the gastronomy tourism development on local rice based on the cultural heritage values; 3) to analyse strategies proposals for the gastronomy tourism development; and 4) to create tourism products as the innovative model for the gastronomy tourism development on local rice based on the cultural heritage values in Mahasarakham.In this study, a mixed-method approach was applied; specifically; qualitative and quantitative research was carried out. In obtaining quantitative data, a questionnaire was employed as a research instrument. The samples in this part included 400 tourists traveling to Phayakkhaphum Phisai district, Borabue district and Wapeepathum district, Mahasarakham. The quantiative data were analyzed through factor analysis, exploratory factor analysis, confirmatory factory analysis and structural modelling analysis. As for collection of qualitative data, in-depth interviews and focus group discussions were conudcted. The participants in in-depth interviews in three districts consisted of seven persons working in the government sector, nine of those in the private sector and fourteen of those in the community sector. In the meantime, the participants in focus group discussions included seven persons working in the government sector, nine of those in the private sector and fourteen of those in the community sector. The collected qualitative data were analyzed with content analysis so as to yield the accurate results and data according to the research objectives.

Keywords: Gastronomy, Tourism Development, Cultural Heritage Values

\section{Introduction}

Food can be a tourist attraction because food is one of the factors that humans must rely upon for their existence. But for most humans, eating to live doesn't seem to match the experience of eating each meal. That's probably because production cooking and eating are activities that have been bound to human cultures for a long time. Since the beginning of agriculture,ingredients for cooking have been produced, and over time, thisprocess has evolved into anart form,as well as a form of cultural exchange or eating food (Ministry of Tourism and Sports, 2016 ). The Northeastern regionof Thailand is especially considered to be a source of food for agricultural products, such as fruits and rice, andMahaSarakham Province isa special area that producesSticky rice and Thung Kula Jasmine rice, which is at the top of the group of provinces. There have been many commercial modifications made to sweet and savory foods, but there has been no concrete activity that haspromoted identity. In MahaSarakham Province, there are tourist sites that have the remains of ancient sites from the Khmer and the Dvaravati periods. In addition, there is an ancient story of food that appeared in the past. This story would be interesting to continue, to expand upon, and to combine with the growth of education, which couldresultin the expansion of various areas of tourism. Moreover,there is the educational center of the Northeastern region,( Tourism Authority of 
Thailand, 2018), whichincludes tourism that combines aspects of the traditional Northeastern flair and which has beenfurther conveyed to the local gastronomic lifestyle. Also, the local food is especially popular, but only in the local areas, which means that there are opportunities to expand. In accordance with the policies, the province has always sought to promote gastronomy tourism, but the results have not been as successful as theycould have been. The aim is to allow tourism to add value to 'Food Heritage' and to the 'Wisdom of Food' through tourism activities, to accomplish this, it is important to create strategies and innovations for the current gastronomy tourism destinations, which are based on food resources from upstream and midstream. It is equally importantto find ways to downstream innovations, which are based on the Cultural Heritage Values of MahaSarakham. Thailand.

\section{Research background}

\section{Cultural Heritage Values}

Cultural Heritage is a long and unique social artifact, which has been accumulated as a social construction. Culture is a reflection of the past successes and the wisdom that have been passed down from previous generations(UNESCO, 2006)Culture also refers to the root and origin of a nation that is worth preserving and maintaining for the next generation as a National Heritage (Laaksonen, Annamari, 2014). There are two types of cultural heritage:Tangible Cultural Heritage and Intangible Cultural Heritage. Intangible Cultural Heritage is defined by UNESCO (2003) as those practices that represent theknowledge and skills that have been wellaccepted by a community as a part of its own Cultural Heritage. Intangible Cultural Heritage is created and passed down through generations via word-of-mouth. Over time, this culture may undergo changes (UNESCO, 2007). The meaningof Intangible Cultural Heritage isCultural Heritage, which is intangible. It isunable to be touched and physically expressed (i.e.,the knowledge, meanings, beliefs, skills, norms, and traditions) that people or communities have created as a part of their lives and that has been transferred from one generation to the next up until the present. Cultural Heritage sites are, therefore, tangible heritage, which comprise immovable cultural properties, which are inseparable from intangible
Cultural Heritage (ICOMOS, 2003). Intangible Cultural Heritage is a gift from previous generations, which can be newly developed to serve the current needs of the community. It also makes one culture stand out fromanother (UNESCO, 2003).

Cultural Heritage not only holds physical value as an invention of the past civilization,but it also imposes a spiritual and mental hold on the people within a community. The followingisa list of qualities that make an artifact become eligible to be considered as Cultural Heritage:

1) Holding historical, academic, and artistic values;

2) Reflecting the evolution of lives and an ethical development from the past to the present;

3) providingan historical footprint, which can be traced to its historical origins;

4) Being unique to one particular community and without being conserved could disappear easily;

5) Reflecting human creativity;

6) Showing the cultural roots of a community;

7) Representing individual or community values;

8) Being at risk of becoming damaged or disappearing when left without conservation.

Cultural Heritage is important because it holds the following values:

1) Historical and Anthropological ValueCultural Heritage portrays community and cultural evolution from the past to the present. It also narrates events relatedto the people and times in history. Beliefs and ideas, which are related to an invention, are embedded ineverysingle piece of cultural artifacts.

2) Social and Political Relation ValueCultural Heritage shows a unique connection between a community's past and its forms of politics and governance. It also narrates the past stories of ancient politics and past policies of governance.

3) Educational Valuethe remaining cultures of the past are a big reliable book that people in the presentcan study to see what was held in the past. Cultural Heritage is an important, rare, and enduring resource for present-day research, which helps the present-day learners to trace development back to the past,in which there are still a lot of hidden facts to be explored. 
4) Aesthetic and Beauty ValueMost of the time, Cultural Heritage involves the great invention of a community, whichhas been beautifully crafted andcan make astrong impressionon visitors.

5) ARepresentativeness ofRarity andIdentity ValueIn the present, those rare cultural artifacts that remain remind people of the beauty of the past cultures.

It can be concluded that the Cultural Heritage holds 19 types of values as follows:
1) Historical Value,
2) Social Value,
3) Living Value,
4) Traditional Value,
5) AuthenticValue,
6) Beauty Value,
7)Rarity Value,
8) Educational Value,
9) Narration Value,
10) Artistic Value,
11) Creativity Value,
12) Conservational Value,
13) Economic Value,
14) Social Image Value,
15) Identity Value,
16) Aesthetic Value,
17) Anthropological Values,
18) Community Value,
19)Archaeological Value.

\section{Tourism Motivations}

Abraham H. Maslow (1954) explained the following: 1) A man is born with needs which are endlessinnature. The needs that have been fulfilled can easily be replaced with other new needs, which means that needs for humans are a never-ending process. Starting from the time when people are born until the time when they die, their needs continue. 2) The needs that have been fulfilled are no longer considered as needs; only the ones that are left without fulfillment are effective for behavioral causation. 3) There are hierarchies of needs starting from low-level needs to higher-level ones, andthe latter requirean immediate response. The five aspects of Maslow's Hierarchy of Needs, ranked from the lowest to the highest are presented below:
1. Physiological Needs are the basic needs for survival,including the need for the four requisites (food, water, air, and accommodation), compliments, and gender-related needs, among others.

2. Safety Needs are another form of survival needs, such as the need for career securityand the need for protection and safety.

3. Social Needs are the needs to be loved, to feel belongingness, and to be accepted as an existing member of a group in a social unit.

4. Esteem Needs are an individual's needs to: be outstanding, be recognized and to obtain social status and a higher level of relationship with other people, as well as to be respected socially.

5. Self-actualization Needsare at the top of the Hierarchy of Needs and are involved with being successful at a high level, which is reckoned by the public as special. This can be exemplified by a famous singer, who can master almost everything in his or her life.

In accordance with Maslow's Law of Inspiration, tourism inspiration is most of all triggered by the need to fulfill biological needs, followed by safety and security needs, relationship needs, selfesteem and development needs, and finally, the needs for happiness and fulfillment. The arrangement of individual needs, which are based on Maslow's Law,can help tourism operators to better cater to the tourists' requirements.

Actually, there are wide varieties of motivations that cause people to make tourism decisions. These can be categorized into two groups in tourism: Push Factors and Pull Factors. Push Factors are the motivators that make people have the desire to travel, while the pull factors are the elements that really cause them take a trip. KirdsiriJaleonwisan and JutamatJantarat( 2000)proposed the following components of the Push Factors and the Pull Factors when deciding to take an overseas trip. The Push Factors for taking an overseas trip are: 1) the need for novelty, 2) the need for Knowledge, 3) the need for Prestige, 4) the need for relaxation,5) the need to Escape, 6) the need to visit relatives and friends, 7) the need to goShopping, and 8) the need to continue one's education.

Based on their instincts, people desire to take a trip. However, tourism motivation is diversified in accordance with the individual's economic and social 
differences. Below is a list of reasons why people take tours: 1) the need to not be entwined with daily routines, 2) the need for excitement,3) the desire to learn something new and novel, 4) the wish to see different social values, 5) the need to explore different cultures, 6) the need to visit friends and relatives, 7) the desire to learn about different ways of life, 8) the need for social recognition, 9) the need for prestige,10) the need for social status, 11) the need to recall the past,12) the need for pleasure, and 13) the need for physical and mental resilience.

\section{Tourists' Experiences}

Laing, Wheeler, Reeves \& Frost (2014) stated that an individual's experience can affect his or her trip, and it is important to foster a positive experience for the tourists. Foster (2014) says holidays are established to allow for excitement and fun experiences. Pine \& Gilmore (1999) noted that tourists want to experience excitement and have good memoriesof their trip. Mei (2014) stated thatmaking travel decisionsis a complex process, which is related to psychological reasons that are diversified from person to person. Neuhofer\&Buhallis(2014) indicatedthat the operators, who can create an impressive experience for tourists, usually gain higher competitive power than other firms, which don't have the same ability. Stamboulis\&Skayannis(2003) suggested that a "tourism experience" is a connection between the tourists and the places that they visit. Richards (2001) notedthat tourism firms can attract tourists via broadcasting the past experiences of the former tourists in order to attract new groups of tourists. Fesenmaier\& Xiang (2014) stated that the tourism experience can be included in the tourism package. Kim, Hallab\& Kim (2012) found that the past tourism experiencesare simulatorsfor the next tourism decision. Impressions related to services, cultural values, and the imagination of the place they are visiting, are the motives for tourism decisions. Tan (2016) stated that tourism scenes are the magnets that prompt former tourists to revisit the locales. It was observed from interviewing the samples for this study that familiarity and having an impressive experience had affected the tourists' decisions to revisit. However, for those revisiting tourists, whose purpose for tourism was to obtain relaxation, it was found their experience and the image of the tourism destination had nothad any impact on their decision to revisit a destination. Poulsson\& Kale (2004) statedthat true tourism experiences can only be generated when tourists take part in tour activities, which have been designed to expose the tourists to learning and to assist them in coming intocontact with other tourists. Meanwhile, it is equally important for the activities to be fun and novel for the tourists. Sonmez\&Graefe(1998) explained that whether or not tourists would choose to return to the same tourism sites depended upon their past experienceson their previous visits. The level of risk at a site and the security systems, which have been put in place there,are the two reasons that have the power to make one tourism attraction become more or less popular among the tourists. These are, of course, factorsthat affect the tourists' decisions torevisit a place. A country with lower levels of risk and higher levels of security can become a favorite overseasdestination for foreign tourists. Having had an impressive past experience is a key factor thatcan make tourists want to return, while risk and security factors can also contribute to the creation of loyaltyfrom the tourists.

\section{Research method}

\subsection{Identification of the factors}

Conducting in-depth interviews is a qualitative research technique that involves conducting intensive individual interviews with a small number of respondentsin order to explore their perspectives on particular ideas, programs, or situations. The process for conducting in-depth interviews follows the same general process, which is followed in other research studies: planning, developing instruments, collecting data, analyzing data, and disseminating findings (Carolyn Boyce, 2006). The research started with identifying the factors, which were related to the theories and the literature, such as research articles and text books. The in-depth interviews wereused as the tool to confirm the factors, to deeply explore new issues, and to formulate the conceptual research model in accordance withthe following steps:

Step 1. Identifyingthe stakeholders, who will be involved. There were 3 different sample groups, who were involved in Gastronomy Tourism Development Focusing on Cultural Heritage Values in Mahasarakham Province. 
Step 2. Identifyingthe information that would be needed and from whom it would be gathered. The respondents consisted of 9 representatives from government agencies and the private sector, 3 entrepreneurs, and 3 community members. In order to cover the research issues and to collect comments from each group of experts, the questions were broad and open-ended.

Step 3. Analyzing all of the interview data. Reading through the interview responses and looking for patterns or themes among the participants.

\section{hypotheses}

\subsection{Conceptual research model and}

In order to study and explain the Gastronomy Tourism Development Focusing on Cultural Heritage
Values, the research hypotheses were created according to the literature mentioned in section 2 which are Cultural Heritage Values, Tourists' Experiences, Tourists' Experiences, the following research hypotheses were determined.

H1: The value of Cultural Heritage Values of local rice products will influence the motivation of Food Tourists in MahaSarakham Province.

$\mathrm{H} 2$ : The values of Cultural Heritage of local rice products will influence the experiences of Food Tourists in MahaSarakham Province.

H3: The Motivation factors of the local Food Tourists will influence the experiences of Food Tourists with respect to local rice in MahaSarakham Province.

Table 1.Initial factors and Items.

\begin{tabular}{|c|c|c|}
\hline Factors & Intermediate Factors & Items \\
\hline \multirow[t]{9}{*}{$\begin{array}{l}\text { Cultural } \\
\text { Heritage Values }\end{array}$} & Historical Value & $\begin{array}{l}\text { HV1 Story Telling } \\
\text { HV2 Life Style } \\
\text { HV3 Local Legend }\end{array}$ \\
\hline & Living Value & $\begin{array}{l}\text { LV1 Wisdom } \\
\text { LV2 Skill } \\
\text { LV3 Folk }\end{array}$ \\
\hline & Authenticity Value & $\begin{array}{l}\text { AUV1 Process } \\
\text { AUV2 Taste } \\
\text { AUV3 Atmosphere }\end{array}$ \\
\hline & Aesthetic value & $\begin{array}{l}\text { ASV1 Artistry } \\
\text { ASV2 Creative } \\
\text { ASV3 Decoration }\end{array}$ \\
\hline & Economic Value & $\begin{array}{l}\text { EV1 CommunityEnterprise } \\
\text { EV2 Value Added } \\
\text { EV3 Tourism Product }\end{array}$ \\
\hline & Social Value & $\begin{array}{l}\text { SV1 Belief } \\
\text { SV2 Norm } \\
\text { SV3 Tradition }\end{array}$ \\
\hline & Educational Value & $\begin{array}{l}\text { ED1 Importance } \\
\text { ED2 Training } \\
\text { ED3 Knowledge }\end{array}$ \\
\hline & Conservation Value & $\begin{array}{l}\text { CS1 Inheritance } \\
\text { CS2 Being Lost } \\
\text { CS3 Significance }\end{array}$ \\
\hline & Identity Value & $\begin{array}{l}\text { IV1 Rarity } \\
\text { IV2 Unique } \\
\text { IV3 Characteristic }\end{array}$ \\
\hline \multicolumn{2}{|l|}{ Tourists' Motivations } & $\begin{array}{l}\text { TM1: Prestige } \\
\text { TM2: Status } \\
\text { TM3: Health Concern }\end{array}$ \\
\hline
\end{tabular}




\begin{tabular}{|l|l|}
\hline \multirow{7}{*}{} & TM4: Culture \\
& TM5: Escape form Routine \\
& TM6: Pleasure \\
& TM7: Sensory Appeal \\
& TM8: Excitement \\
& TM9: Togetherness \\
& TM10: Interpersonal \\
\hline Tourists' Experiences & TE1: Hedonism \\
& TE2: Novelty \\
& TE3: Local Culture \\
& TE4: Refreshment \\
& TE5: Meaningfulness \\
& TE6: Involvement \\
& TE7: Knowledge \\
& TE8: Adverse Experience \\
\hline
\end{tabular}

Once the hypotheses were established, a conceptual research model would be formulated according to those hypotheses. Hence, the conceptual research model could be drawn (Figure 1).

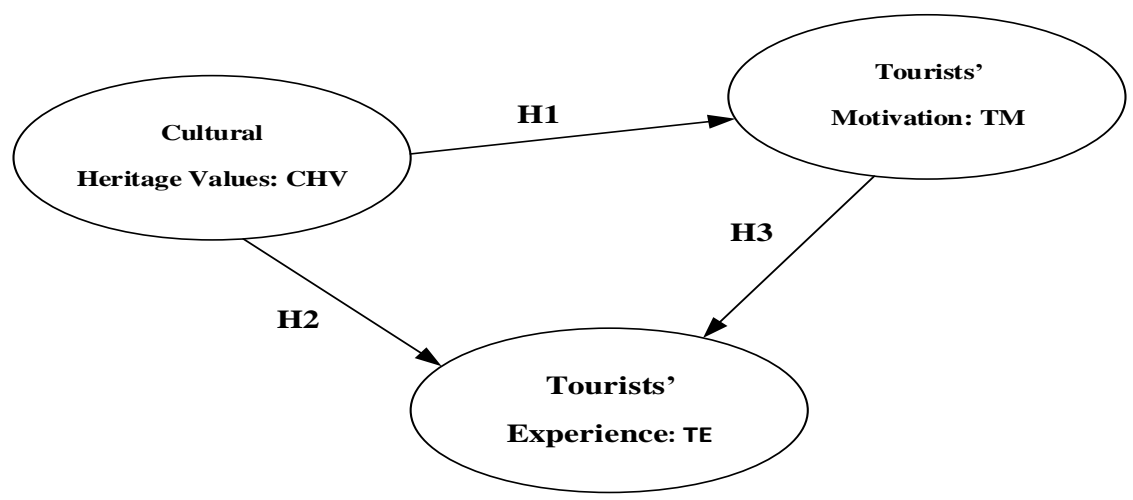

Figure 1.TheResearch hypothesis

\subsection{Questionnaire design}

The questionnaire was used to collect the data relevant to the causal factors/items of the Gastronomy Tourism Development Focusing on Cultural Heritage Values in this research. The questions in the questionnaire were designed based on the initial factors/items stated in Table 1. The questionnaire was comprised of six parts. The first part aimed to elicit general information of the respondents. The second part was about the perception of tourists towards Cultural Heritage Values. The third part intended to examine the opinions about the Value, Heritage. The fourth part involved the motivation of food tourism based on Cultural Heritage Values. The fifth part was about the expected experiences of food tourists on Cultural Heritage Values and the sixth part was about additional comments and suggestions.

\subsection{Validity and reliability test}

Forty of the improved questionnaires were tested out with tourists in the area that have similar art, culture, and terrainwith MahaSarakham Province.Before distributing the questionnaires to the sample groups in this study, the test data was retrieved and analyzed in order to check for reliability utilizing the method of calculating the number of questionnaires that are going to be used for trial ( Try Out) .Using content validity, thequestionnaires were validated by specialists. In order to ensure the quality of the questionnaires, they were then tested. Next, the reliability of the questionnaires was validated by using Cronbach's Alpha, which is a reliability coefficient of internal consistency with the following formula (Cronbach, 1970) .From the 45 questions in the questionnaire, the Cronbach's Alpha analysis indicated 
that Cronbach's Alpha had been 0.915, as shown in Table 2 .
Table 2Shows the Reliability of the questionnaire.

\section{Reliability Statistics}

\begin{tabular}{|c|c|}
\hline $\begin{array}{c}\text { Cronbach's } \\
\text { Alpha }\end{array}$ & N of Items \\
\hline 0.915 & 45 \\
\hline
\end{tabular}

4) Data was gathered from the focus groups

\subsection{Data collection}

The target population of this study was Thai tourist who came to visit MahaSarakham province. The data was collected from the following:

1)Questionnaireswere gathered from groups of tourists.

2) Questionnaires were obtained from people within the community.

3) The interview form was collected from government agencies and private agencies, entrepreneurs, and experts from various disciplines. consisting ofmembers of government agencies and related agencies; private agencies; entrepreneurs; and experts from various disciplines.

\subsection{Model development}

The model development began by using a statistical technique called Exploratory Factor Analysis (EFA), tocategorize the exogenous factors (or causal variables) of the model. Then the exogenous factors were formulated totest the model fit using a measurement model. Finally, a structural model was formulated from the measurementmodel and the endogenous factors.

\section{Results}

\subsection{Descriptive results}

Table 3.The Results of general data analysis of respondents

\begin{tabular}{|c|c|c|}
\hline The General Information of the Respondents & Numbers & Percentages \\
\hline \multicolumn{3}{|l|}{ 1. Genders } \\
\hline - Male & 141 & 35.3 \\
\hline - Female & 259 & 64.8 \\
\hline Total & 400 & 100 \\
\hline \multicolumn{3}{|l|}{ 2. Ages } \\
\hline$-10-20$ years of age & 89 & 22.3 \\
\hline - 21-30 years of age & 151 & 37.8 \\
\hline - 31-40 years of age & 98 & 24.5 \\
\hline$-41-50$ years of age & 23 & 5.8 \\
\hline - 51 years old and above & 39 & 9.8 \\
\hline Total & 400 & 100 \\
\hline \multicolumn{3}{|l|}{ 3. Marital Status } \\
\hline - Single & 283 & 70.8 \\
\hline - Married & 108 & 27.0 \\
\hline - Divorced & 0 & 0 \\
\hline - Widowed & 9 & 2.3 \\
\hline - Other & 0 & 0 \\
\hline Total & 400 & 100 \\
\hline
\end{tabular}




\begin{tabular}{|c|c|c|}
\hline The General Information of the Respondents & Numbers & Percentages \\
\hline $\begin{array}{l}\text { 4. Levels of Education } \\
\text { - Elementary School Level or equivalent } \\
\text { - Secondary School Levelor equivalent } \\
\text { - Bachelor's degree or equivalent } \\
\text { - Postgraduate } \\
\text { - Other }\end{array}$ & $\begin{array}{c}10 \\
110 \\
229 \\
32 \\
19\end{array}$ & $\begin{array}{c}2.5 \\
27.5 \\
57.3 \\
8.0 \\
4.8\end{array}$ \\
\hline Total & 400 & 100 \\
\hline $\begin{array}{l}\text { 5. Monthly Incomes } \\
-5,000 \text { baht or less } \\
-5,001-10,000 \text { baht } \\
-10,001-15,000 \text { baht } \\
-15,001-20,000 \text { baht } \\
\text { - 20,001-25,000 baht } \\
\text { - More than } 25,000\end{array}$ & $\begin{array}{l}128 \\
91 \\
63 \\
48 \\
19 \\
51\end{array}$ & $\begin{array}{c}32.0 \\
22.8 \\
15.8 \\
12.0 \\
4.8 \\
12.8\end{array}$ \\
\hline Total & 400 & 100 \\
\hline $\begin{array}{l}\text { 6. Occupations } \\
\text { - Private business owner } \\
\text { - Civil servant / State enterprise employee } \\
\text { - Company employee } \\
\text { - Student/university student } \\
\text { - General employee } \\
\text { - Private Business } \\
\text { - Retired } \\
\text { - Others (Specific)............ }\end{array}$ & $\begin{array}{c}89 \\
42 \\
52 \\
160 \\
38 \\
0 \\
19 \\
0\end{array}$ & $\begin{array}{c}22.3 \\
10.5 \\
13.0 \\
40.0 \\
9.5 \\
0 \\
4.8 \\
0\end{array}$ \\
\hline Total & 400 & 100 \\
\hline $\begin{array}{l}\text { 7. Birthplaces } \\
\text { - Bangkok } \\
\text { - Kalasin } \\
\text { - KhonKaen } \\
\text { - Chaiyaphum } \\
\text { - Chiang Mai } \\
\text { - NakhonRatchasima } \\
\text { - Buriram } \\
\text { - Phuket } \\
\text { - MahaSarakham } \\
\text { - Roi Et } \\
\text { - Lamphun } \\
\text { - Loei } \\
\text { - Sisaket } \\
\text { - Saraburi } \\
\text { - NongBua Lam Phu } \\
\text { - Amnat Charoen } \\
\text { - UdonThani }\end{array}$ & $\begin{array}{c}18 \\
16 \\
158 \\
28 \\
9 \\
13 \\
9 \\
1 \\
45 \\
1 \\
9 \\
37 \\
1 \\
9 \\
9 \\
1 \\
36\end{array}$ & $\begin{array}{c}4.5 \\
4.0 \\
39.5 \\
7.0 \\
2.3 \\
3.3 \\
2.3 \\
0.3 \\
11.3 \\
.3 \\
2.3 \\
9.3 \\
0.3 \\
2.3 \\
2.3 \\
0.3 \\
9.0\end{array}$ \\
\hline 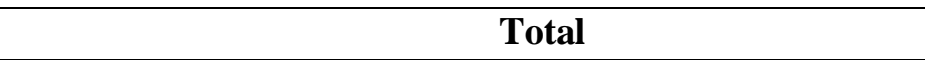 & 400 & 100 \\
\hline
\end{tabular}




\subsection{Exploratory factor analysis}

Table 4 the Factor Loading for the Exploratory Factor Analysis

\begin{tabular}{|c|c|c|c|c|c|c|c|c|c|}
\hline \multirow[t]{2}{*}{ Item } & \multicolumn{7}{|c|}{ Component } & \multirow{2}{*}{\multicolumn{2}{|c|}{ Cronbach's $\alpha$}} \\
\hline & 1 & 2 & 3 & 4 & 5 & 6 & 7 & & \\
\hline AUV2 & .923 & .106 & .130 & .032 & .059 & .094 & .067 & \multirow{6}{*}{0.916} & \multirow{27}{*}{.907} \\
\hline HV1 & .919 & .094 & .111 & .021 & .078 & .115 & .054 & & \\
\hline LV1 & .874 & .198 & .040 & .036 & -.048 & .133 & .161 & & \\
\hline AUV1 & .824 & .098 & -.006 & -.034 & .438 & .023 & -.127 & & \\
\hline ASV3 & .686 & .064 & .381 & .016 & .240 & .116 & .411 & & \\
\hline HV2 & .656 & .071 & .035 & .109 & .529 & -.022 & .197 & & \\
\hline ED1 & .089 & .864 & .077 & .007 & .101 & .043 & -.002 & \multirow{8}{*}{0.905} & \\
\hline CS1 & .067 & .786 & -.145 & .019 & .083 & .292 & .104 & & \\
\hline EV1 & .121 & .776 & .086 & .256 & -.139 & -.011 & .003 & & \\
\hline EV2 & .203 & .745 & .097 & .109 & -.320 & .061 & -.161 & & \\
\hline ED2 & .031 & .706 & -.031 & .219 & .081 & .250 & .250 & & \\
\hline ED3 & .038 & .689 & .185 & .325 & .179 & .229 & -.034 & & \\
\hline EV3 & .141 & .605 & .088 & .376 & .106 & .162 & -.360 & & \\
\hline SV1 & .150 & .544 & .090 & .470 & -.087 & .254 & .126 & & \\
\hline ASV2 & .025 & .094 & .923 & -.008 & .179 & -.031 & .013 & \multirow[t]{2}{*}{0.722} & \\
\hline ASV1 & .300 & .104 & .854 & .028 & .202 & .004 & .164 & & \\
\hline CS3 & -.012 & .148 & .130 & .720 & -.137 & .268 & .227 & \multirow{4}{*}{0.788} & \\
\hline SV3 & .000 & .407 & .075 & .620 & .016 & -.103 & -.405 & & \\
\hline SV2 & .027 & .234 & -.245 & .601 & .233 & .151 & -.041 & & \\
\hline CS2 & .025 & .391 & .013 & .506 & -.041 & .317 & .216 & & \\
\hline HV3 & .416 & -.001 & .311 & -.017 & .784 & .045 & -.090 & \multirow[t]{2}{*}{0.884} & \\
\hline LV3 & .305 & -.043 & .386 & .010 & .730 & -.025 & .269 & & \\
\hline IV1 & .007 & .271 & -.062 & .104 & .227 & .755 & .182 & \multirow{3}{*}{0.736} & \\
\hline IV2 & .156 & .231 & .164 & .347 & -.047 & .744 & -.137 & & \\
\hline IV3 & .195 & .156 & -.103 & .110 & -.130 & .675 & -.153 & & \\
\hline LV2 & .478 & .051 & & .102 & .237 & -.088 & .730 & \multirow[t]{2}{*}{0.801} & \\
\hline AUV3 & .194 & .078 & & .097 & -.026 & -.053 & .721 & & \\
\hline
\end{tabular}

With respect to the Exploratory Factor Analysis,the opinions of the respondents in Part 3 on the Cultural Heritage Values of Local Rice Products in MahaSarakham have 27 topicsarising from 9 factors. In order to be defined as variables, those variables with similar analysis results were placed into the same variable group, which is called a factor or an element. The analysis of the exploratory factors in this research utilized the Varimax axis rotation technique to group the variables. The data was entered into the programwith the Kaiser-Meyer-Olkin( KMO) $>0.6$ (Tabachnik and Fidel, 2001) and with Bartlett's Test of Sphericity $=0.000$ (Sig.). After that, the probability (Reliability) of all factors was checked.

Next, the data was entered into the program withKaiser-Meyer-Olkin $(\mathrm{KMO})=0.930(\mathrm{KMO}>0.6)$ (Tabachnik and Fidel, 2001 ) and Bartlett's Test of Sphericity $=0.000$ (Sig.). After that, the reliability of all factors was checked. The 3 parts had 7 factors $(1,2$, $3,4,5,6$, and 7 ), and their Cronbach's Alpha values were $0.916,0.905,0.722,0.788,0.884,0.736$, and
0.801 ,respectively. Those, which had a value of greater than 0.7 (Cronbach's> 0.7) (Nunnally, 1987), were considered to be reliable. An analysis of the results is shown in Table 4

\subsection{Measurement model}

By inputting the initial model into the finished program in order to carry out the Confirmatory Factor Analysis, it was found that the model did not yet fit. Therefore, it was necessary to improve the model by considering the MI (Modification Indices). It was found that there were some pairs of variables in the model that had givenrelevant results. Therefore, the researcher used variable cutting methods. The Factor A group was able to cut the variables, AUV2, LV1, HV1, and AUV1, whereas, the Factor F group was able to cut the variable IV2 and was able to also cut the Groups B, D, E, and G. As a result,a perfectly formed model was created (Fit). The values of the Chi-square $=10.710$, thedf $=6$, the $\mathrm{p}=.098(>.05)$, theCMIN $/ \mathrm{DF}=$ $1.785(<3)$, theGFI $=.991(>.90)$, and theRMSEA $=$ .044 (<.08) (Arbuckle, 2011). 


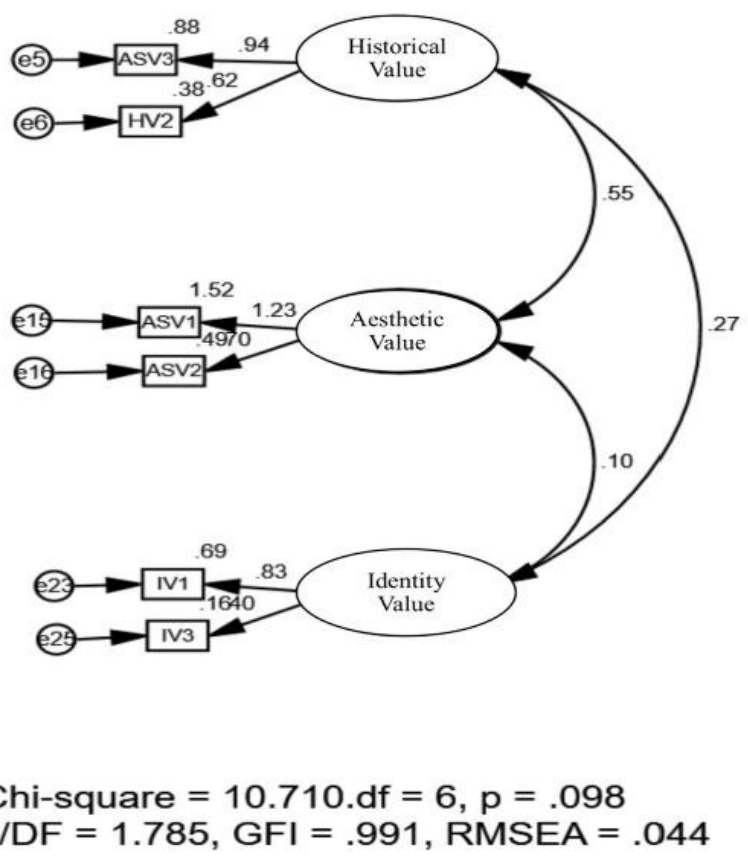

Fig. 2. Measurement model

\subsection{Structural model}

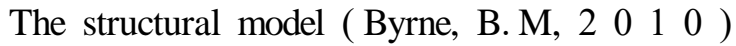
illustrates the 'influence' between the factors or latent variables, whichhave effects on the other factors in the empirical data collected from the sample group. In order to confirm the results, the structural model was compared to one that was a model fit. The researcher has noted the results of the analysis of the structural model oflocal rice productsbased on Cultural Heritage Values in MahaSarakham Province, which are not yet fully formed ( Not Fit) as shown in Figure 4 .15To improve the model,the following Modification Indices were considered in order to obtain a well-structured model: a) ( fit) atCMIN- $p$ (Chi-square Probability Level) $>0.05$, b) CMIN/DF (Relative Chi-square) $<3$, c) GFI (Goodness of Fit Index) $>0.90$, andd) RMSEA (Root Average Square Error of Approximation) <.0 8 (Arbuckle, 2011). The results of the Structural Model Analysis are as follows:

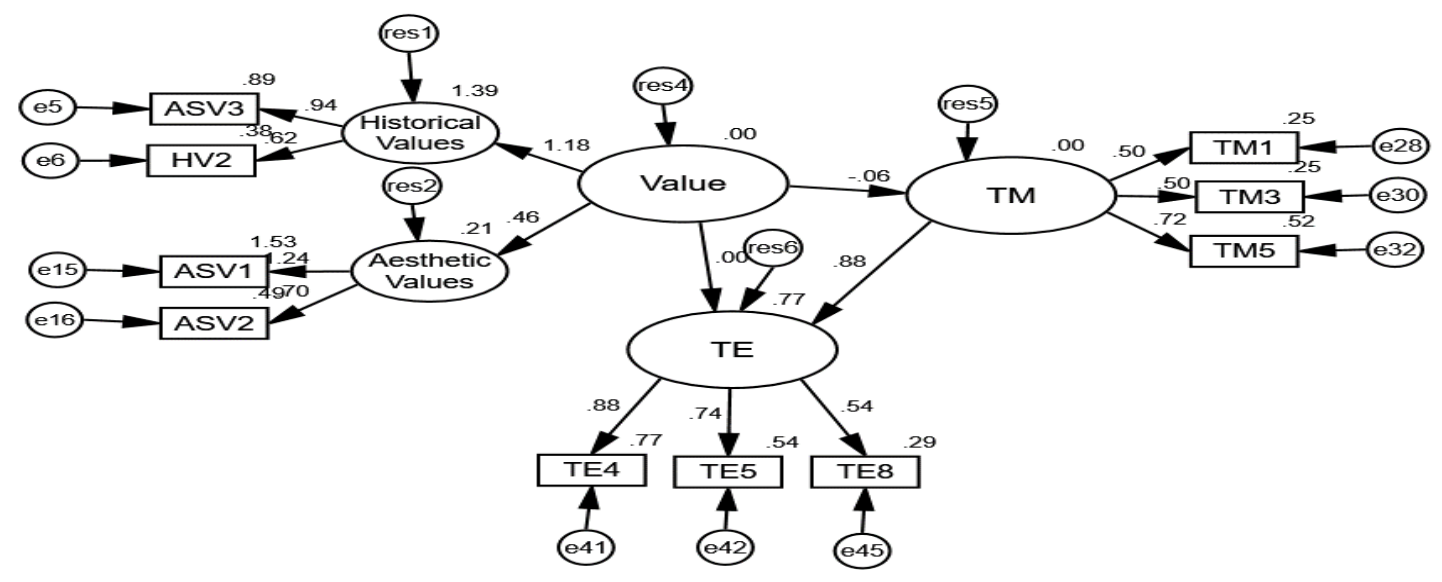

Chi-square $=41.313 . \mathrm{df}=30, \mathrm{p}=.082$

CMIN/DF = 1.377, GFI = .979, RMSEA = .031 
Figure 3The Structural model

Consequently, the research hypotheses were tested according to the outputs of the structural model. The results ofthe test are presented in Table 5.
Table 5 The Results of the Hypothesis Testingfromthe Structural Modelof Local Rice Productsbased on the Cultural Heritage Values in MahaSarakhamProvince

\begin{tabular}{|c|c|c|c|c|}
\hline Hypotheses & Relationships & $\begin{array}{c}\text { Standardized } \\
\text { Path } \\
\text { Coefficient }\end{array}$ & Results & $\begin{array}{c}\text { Significance } \\
(\boldsymbol{p})\end{array}$ \\
\hline H1 & $\begin{array}{c}\text { Cultural Heritage Values (CHV) } \\
\text {----> Tourists' Motivations (TM) }\end{array}$ & -0.065 & Rejected & 0.458 \\
\hline H2 & $\begin{array}{c}\text { Cultural Heritage Values(CHV) } \\
---->\text { Tourists' Experiences } \\
\text { (TE) }\end{array}$ & -0.003 & Rejected & 0.936 \\
\hline H3 & $\begin{array}{c}\text { Tourists' Motivations (TM) } \\
\rightarrow \text { Tourists' Experiences (TE) }\end{array}$ & 0.879 & Supported & 0.001 \\
\hline \multicolumn{4}{|r|}{ Note: *** $=p<.001$} & \\
\hline
\end{tabular}

From Table 5 and Figure 1 The Results of Hypothesis Testingfromthe Structural Model of Local Rice Productsbased on the Cultural Heritage Values in MahaSarakham Provincecould easily explain the following: The Cultural Heritage Values had not affected the Tourists' Motivations andThe Cultural Heritage Values had not affected the Tourists' Experiences,but theTourist's Motivations had significant impact on the expected Tourists'Experiences.

\subsection{Model modification}

According to Figure 4 the Final Structural Model of Local Rice Products based on the Cultural Heritage Values in MahaSarakham Province found that the

Cultural Heritage Values had consisted of 2 parts as follows:

1) Factor Historical Value Group had consisted of Decoration with local herbs (ASV3) with the first weight of (0.94), followed by Local Wisdom (HV2) with the weight of (0.62).
2) Factor Aesthetic Value Group had consisted of Creative (ASV1) with weight at first rank (1.24) and Artistic (ASV2) with a weight of (0.70).

The Tourists' Motivations had consisted of Escape from Routines (TM5 ) with first weight of (0.72), and then Prestige (TM1) and Health Concerns (TM3), followed by the weight of $(0.50)$.

Tourists' Experiences had included Refreshment (TE4) with the first weight of $(0.88)$, Meaningfulness (TE5) with the weight of $(0.74)$, followed by Adverse Experience (TE8 ) with the weight of (0.54) as the last order.

From the analysis, it was found that the Cultural Heritage Values had not affected the Tourists' Motivations (Reject H1) $(\mathrm{P}$-value $=0.458>0.05)$ and that Cultural Heritage Values had not affected the Tourists' Experiences ( Reject H2 ) ( P-value = $0.936>0.05)$. However, it was found that The Tourists' Motivations had affected Tourists' Experiences ( Sig H3) $($ P-value $=0.001<0.05)$.

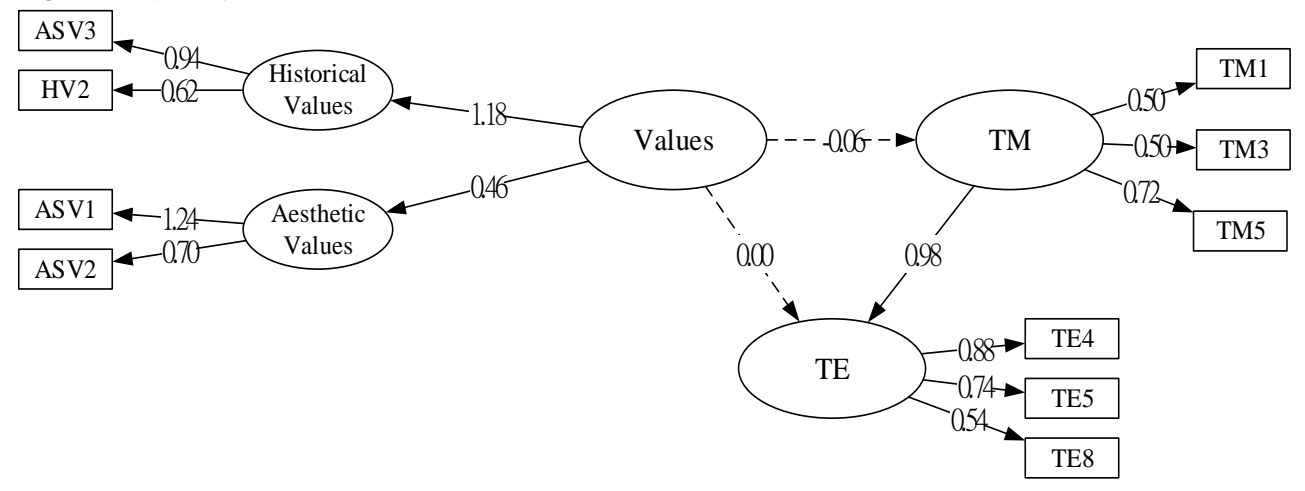

Chi-square $=41.313 \mathrm{df}=30, \mathrm{p}=.082$ $\mathrm{CMIN} / \mathrm{DF}=1.377, \mathrm{GFI}=.979, \mathrm{RMSEA}=.031$

Figure 4The Final Structural model 
Therefore, the researcher can conclude thatthe Factors related to Local Rice Products based on the Cultural Heritage Values in MahaSarakham Province can be used to recognize relevant factors in order to make various developmental plans so that tourism can be promoted in the future. In the next chapter, the researcher concludes the results of the study, thediscussion of the study's findings, and suggestions.

\section{Conclusion}

The Structural Model obtained from Local Rice based on the Cultural Heritage Values of MahaSarakham ProvinceFrom this study, a structural modelwas established, which can be used as a model for Local Rice food based on the Cultural Heritage Values in MahaSarakham Province, as shown in Figure 5

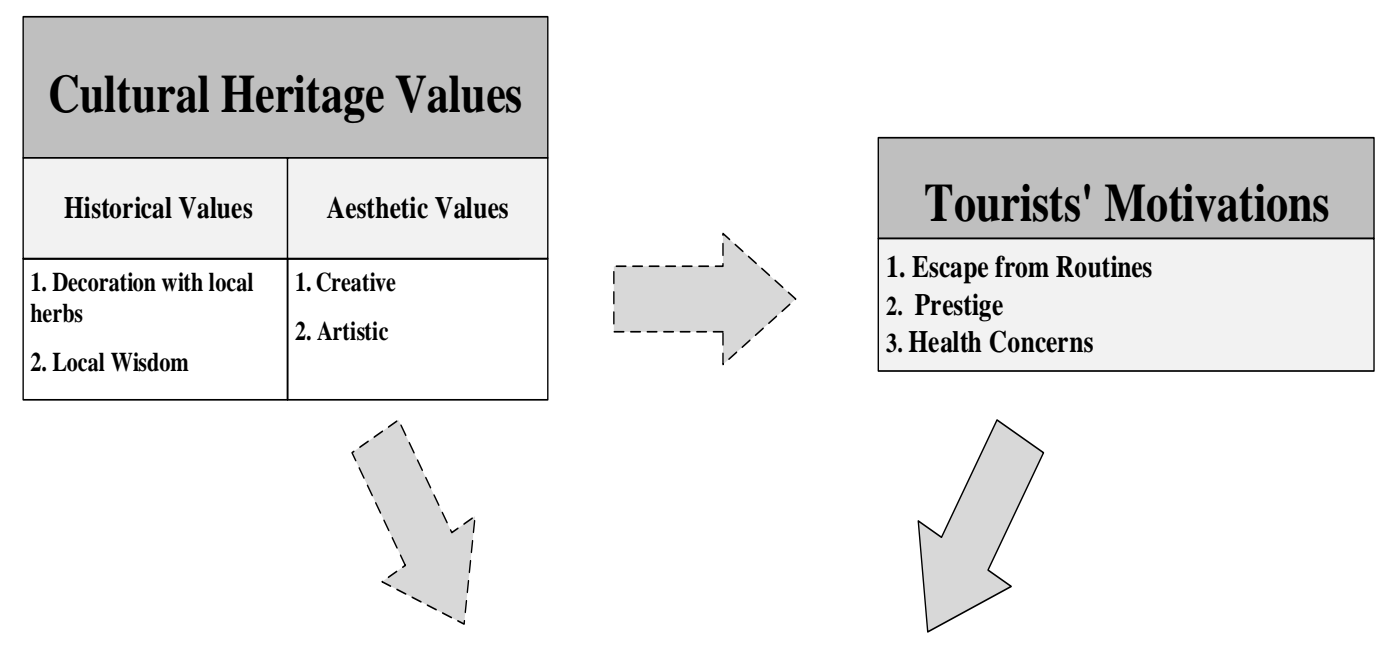

\section{Tourists' Experiences}

1. Refreshment

2. Meaningfulness

3. Adverse Experience

Figure 5TheModel of the Local Rice foods based on the Cultural Heritage Values of MahaSarakham

Province

In this study, it was found that Tourists 'Motivations had affected the expected Tourists' Experiences $(\mathrm{Sig} \mathrm{H} 3)(\mathrm{P}$-value $=0.001<0.05)$. The most influential Tourists' Motivation was theEscape from Routine ( TM5 ), which hadshown a weight of 0.72 , and the Tourists' Experiences that had the most effect wereRefreshment (TE4) with a weight of 0.88 .

At the same time, the cultural heritage values in MahaSarakham Province did not affect the motivation and experience of tourists. May be caused by differences in context.Culture, traditions, religion and way of life of tourists.

\section{Acknowledgements}

This research study was supported by the National Research Council of Thailand ( NRCT) : Research Scholarship for Graduate Students in 2018.

This article is part of a thesis entitled, "Innovation for Gastronomy Tourism Development Focusing on Local Rice Products and the Cultural Heritage Values of Mahasarakham Province" for the Doctor of Philosophy Program in Tourism and Hospitality Innovation Management at the Faculty of Business Administration and Accountancy at KhonKaen University in Thailand.

\section{References}

Abraham, M.H. (1954). The instinctoid nature of basic needs.Retrieved June 5, 2017, from https://psycnet.apa.org/record/1955-00357001.

Arbuckle, J. (2011). IBM SPSS Amos 20 User's Guide. Mount Pleasant Amos Development Corporation. 
Boyce, C. and Neale, P. (2006) Conducting In-Depth Interview: A Guide for Designing and Conducting In-Depth Interviews for Evaluation Input. Pathfinder International Tool Series, Monitoring and Evaluation-2.

Byrne, B. M. (2010). Structural equation modeling with AMOS: Basic concepts, applications, and programming. 2nd Edition.Routledge Taylor

$\&$ Francis Group.

Carolyn Boyce. (2006). CONDUCTING IN-DEPTH INTERVIEWS: A Guide for Designing and Conducting In-Depth Interviews for Evaluation Input. PATHFINDER INTERNATIONAL TOOL SERIES.Monitoring and Evaluation - 2 .

Cronbach, L. J. (1970). Essentials of Psychological Testing. New York: Harper \& Row.

Fesenmaier\& Xiang. (2014). Information technology and consumer behavior in travel and tourism: Insights from travel planning using the internet. Journal of Retailing and Consumer Services, 22(January), 244-249.

Foster, G.D. (2014). Placement and promotion strategies to increase sales of healthier products in supermarkets in low-income, ethnically diverse neighborhoods: a randomized controlled trial. The American Journal of Clinical Nutrition, 99(6), 13591368.

ICOMOS.(2003). ICOMOS Principles for the Preservation and Conservation/Restoration of Wall Paintings. Retrieved June 5, 2017, from https://www.icomos.org/en/what-wedo/focus/179-articles-enfrancais/ressources/charters-andstandards/166-icomosprinciples-for-thepreservation-and-conservationrestoration-ofwall-paintings

Kasetsiri, C. (1997). Thai ways: cultural tourism. Bangkok: The vision project.

Kim, K., Hallab, Z., \& Kim, J.N. (2012). The Moderating Effect of Travel Experience in a Destination on the Relationship between the Destination Image and the Intention to revisit. Hospitality Marketing \& Management, 21(5), 486-505.

KirdsiriJaleonwisan\&JutamatJantarat. (2000). The contentment and motivation for tourism: To promote Thailand to Thailand. TAT Review Magazine, 4(2000), October-December.

Laaksonen, Annamari. (2014). Cultural policies and the 2005 UNESCO Convention in Asia. Research and report prepared by AnnamariLaaksonen, Research Manager, IFACCA, with the support of UNESCO Bangkok Officewww.ifacca.org

Laing, J., Wheeler, F., Reeves, K., \& Frost, W. (2014).Sustainable Tourism and Indigenous Peoples.Retrieved June 5, 2017.

MahaSarakham Provincial Office.(2013). Information for provincial development planning, MahaSarakham Province.MahaSarakham: Information and communication Information group, MahaSarakham Provincial Office.

MahaSarakham Provincial Office.(2019). General information of MahaSarakham Province.MahaSarakham: Strategy and Information Group for Provincial Development MahaSarakham Provincial Office.

Maneenat, T. (2013).12 months tradition in northeast. Retrieved April 12, 2017,

from http://www.finearts.go.th/nakhonphanomlibrar $\mathrm{y} /$ parameters $/ \mathrm{km} /$ item

Mei, X.Y. (2014). Boring and expensive: The challenge of developing experience-based Tourism in the Inland region, Norway. Retrieved June 5, 2017, from https://doi.org/10.1016/j.tmp.2014.09.003.

Ministry of Tourism and Sports, Thailand. (2016). Tourism is the main income of Thailand. Retrieved April 20, 2018, from http://www.tica.or.th/images/ plan_tourism2560-2564/2560-2564.pdf.

Neuhofer, B. (2014). A typology of technology enhanced tourism experiences. International Journal of Tourism Research, 16(4), 340-350.

Pine, G. (1999). Pine and Gilmore's concept of experience economy and its dimensions: An empirical examination in tourism. Journal of Quality Assurance in Hospitality \& Tourism, 12(4), 237-255.

Poulsson, Susanne H.G.; Kale, Sudhir H. Source: The Marketing Review, Volume 4, Number 3, Autumn 2004, pp. 267-277(11). 
Ramitanon, C. (2011). Concept in study of Thai identity. Bangkok: King Mongkut's University of Technology Thonburi.

Richards, J.C. (2001). Curriculum Development in Language Teaching.Cambridge: Cambridge University Press.

Sonmez, G. (1998). Determining future travel behavior from past travel experience and perceptions of risk and safety. Travel Research, 37(2), 171177.

Stamboulis\&Skayannis.(2003). Innovation Strategies and Technology for Experience-Based Tourism Online Journal. Tourism Management, 24(1), 35-43.

Tan. (2016). Completing China's Interest Rate Liberalization. Retrieved June 5, 2017, from https://doi.org/10.1111/cwe.12148.

Tourism Authority of Thailand.(2018). North East Thailand.Retrieved June 5, 2017, from https://www.tourismthailand.org/Destinations/ North-East/5

Umit, S. \&Halil, A. (2016).Gastronomy in Tourism.Procedia Economics and Finance, (39), 725-730.

United Nations Sciences and Cultural Education Organization.(2003). Intangible Heritage domains in the 2003 Convention. Retrieved June 5, 2017, from https://ich.unesco.org/en/intangible-heritagedomains-00052

UNESCO.(2003). ICOMOS Principles for the Preservation and Conservation/Restoration of Wall Paintings. Retrieved June 5, 2017, from https://www.icomos.org/en/what-wedo/focus/179-articles-enfrancais/ressources/charters-andstandards/166-icomosprinciples-for-thepreservation-and-conservationrestoration-ofwall-paintings

UNESCO.(2004). Tangible cultural heritage. Retrieved June 5, 2017, from http://www.unesco.org/new/en/cairo/culture/ta ngible-cultural-heritage/.

UNESCO.(2006). Towards Sustainable Strategies for Creative Tourism. Paper presented at the Planning Meeting for 2008 International Conference on Creative Tourism, SantaFe, New Mexico, USA.
UNESCO. (2007). UNESCO-EIIHCAP regional meeting safeguarding intangible Heritage and Sustainable Cultural Tourism: Opportunities and Challenges. Paris: UNESCO. 